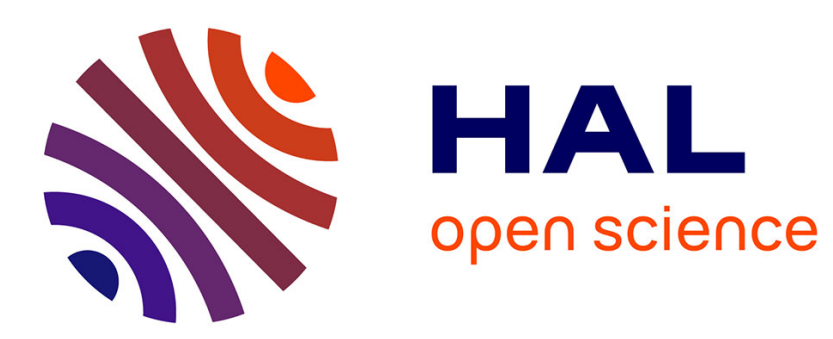

\title{
Alloy corrosion in a coal gasification system
}

N. Simms, J. Norton, T.M. Lowe

\section{To cite this version:}

N. Simms, J. Norton, T.M. Lowe. Alloy corrosion in a coal gasification system. Journal de Physique IV Proceedings, 1993, 03 (C9), pp.C9- 807-C9-816. 10.1051/jp4:1993984 . jpa-00252426

\section{HAL Id: jpa-00252426 https://hal.science/jpa-00252426}

Submitted on 1 Jan 1993

HAL is a multi-disciplinary open access archive for the deposit and dissemination of scientific research documents, whether they are published or not. The documents may come from teaching and research institutions in France or abroad, or from public or private research centers.
L'archive ouverte pluridisciplinaire HAL, est destinée au dépôt et à la diffusion de documents scientifiques de niveau recherche, publiés ou non, émanant des établissements d'enseignement et de recherche français ou étrangers, des laboratoires publics ou privés. 


\title{
Alloy corrosion in a coal gasification system(*)
}

\author{
N.J. Simms $\left({ }^{1}\right)$, J.F. Norton $\left({ }^{2}\right)$ and T.M. Lowe $\left({ }^{1}\right)$
}

( $\left.{ }^{1}\right)$ British Coal Corporation, Coal Research Establishment, Stoke Orchard, Cheltenham, Glos., GL52 4RZ, U.K.

$\left({ }^{2}\right)$ Commission of the European Communities, Institute of Advanced Materials, JRC Petten, PO Box 2, 1755 ZG, Petten, The Netherlands

\begin{abstract}
The corrosion performance of alloys in coal gasification systems is of increasing industrial interest as more advanced coal-fired power generating systems are developed. It is necessary to consider the performance of candidate materials under likely exposure conditions to ensure that components have adequate lifetimes. Materials performance can influence the economic feasibility of these systems. This paper reports the high temperature corrosion performance of a range of materials exposed in British Coal's air-blown, spouted fluidised bed coal gasification pilot plant. The exposures were carried out in the hot gas path of this plant for periods of up to 660 hours, in three distinct temperature ranges between 330 and $920^{\circ} \mathrm{C}$ (i.e. ranges representative of possible evaporator, superheater and ductwork conditions). By characterising the gasifier product gas using carefully selected elements and compounds, activity windows have been defined for sulphur and oxygen for this environment in the required temperature ranges. Standard metallurgical analyses were carried out on exposed alloys to determine their performance in the required temperature ranges. It was found that MA956 performed best in the higher temperature ranges, whilst alloys containing $22-28 \%$ chromium performed better in the lower temperature ranges.
\end{abstract}

\section{Introduction.}

The development of coal gasification plant, especially for use in combined cycle power generation systems, has led to the need to identify materials to withstand the corrosive product gas found in such systems during periods of operation and downtime [1]. The combination of $\mathrm{CO}, \mathrm{CO}_{2}, \mathrm{CH}_{4}, \mathrm{H}_{2}, \mathrm{H}_{2} \mathrm{~S}, \mathrm{H}_{2} \mathrm{O}, \mathrm{N}_{2}, \mathrm{NH}_{3}$, and $\mathrm{HCl}$ found in gasifier product gas can result in complex corrosive degradation, including oxidisation, sulphidation and carburisation [2]. Sulphidation in particular can cause rapid attack on metallic materials [2]. As a result, candidate alloys are those which form protective $\mathrm{Cr}_{2} \mathrm{O}_{3}$ and $\mathrm{Al}_{2} \mathrm{O}_{3}$ scales for these environments. Of particular interest are alloys for use at temperatures up to $\sim 450^{\circ} \mathrm{C}$ for evaporators. Materials for use in superheaters (i.e. up to $\sim 650^{\circ} \mathrm{C}$ ) are of interest and materials suitable for use as uncooled ductwork or instrumentation probes (i.e. up to $\sim 950{ }^{\circ} \mathrm{C}$ ) would be desirable in some gasification systems. Component lives of $10-25$ years are required, which with a corrosion allowance of $5 \mathrm{~mm}$, for example, would require maximum metal loss rates in the range of $23-57 \mu \mathrm{m} / 1000$ hours.

There are several types of gasification processes, e.g. fixed bed, fluidised bed or entrained flow [3], which all operate at pressure in power generation systems. The gasifier used in these studies was an atmospheric pressure gasifier pilot plant, based on British Coal's air blown

$\left(^{*}\right)$ C British Coal Corporation London 1993. 
spouted fluidised bed technology, located at the Coal Research Establishment, Cheltenham, England [4]. This air-blown type of gasifier results in a product gas that is more oxidising than the product gas from other oxygen-blown gasification processes.

Inititally a gas characterisation study was carried out which exposed various elements and compounds in the temperature ranges of interest. In subsequent plant runs, ten possible candidate alloys, based on iron, nickel and cobalt, were exposed at similar temperatures. This paper reports the results of this gas characterisation study and the comparative performances of the alloys in relation to their compositions.

\section{Experimental.}

2.1 PLANT DESCRIPTION AND PROBE LOCATIONS. - The coal gasification pilot plant used in this study was an atmospheric pressure, air-blown, spouted fluidised bed coal gasifier which consumed $\sim 12$ tons coal/day. The materials samples were exposed on thermocoupled probes near to the inlet, middle and exit from the product gas cooler (Fig. 1). The operating conditions of the gasifier plant during the three runs (A, B and $\mathrm{C}$ ) in this study are shown in table I. The compositions of the product gas and the range of temperatures observed on the sample probes are given in table II.

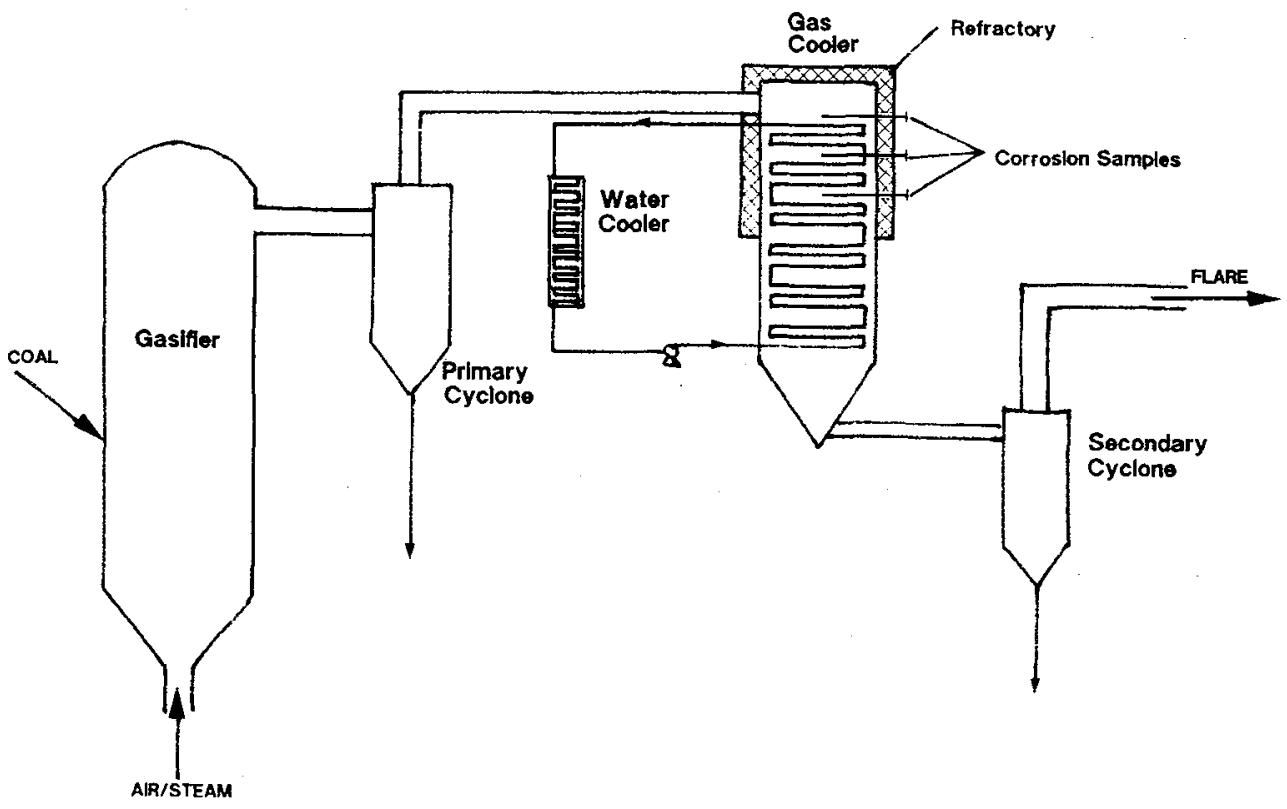

Fig. 1. - Schematic diagram showing the layout of british coal's atmospheric pressure gasifier pilot plant. 
Table I. - Operating conditions of gasifier plant.

\begin{tabular}{|c|c|c|c|}
\hline Operating Conditions & Run $A$ & Run $B$ & Run $C$ \\
\hline Sample Exposure Time & & $960 \mathrm{~h}$ & $890 \mathrm{~h}$ \\
\hline Coal Feed Time & $550 \mathrm{~h}$ & $660 \mathrm{~h}$ & $616 h^{*}$ \\
\hline Limestone Feed Time & & $32 \mathrm{~h}$ & $77 \mathrm{~h}$ \\
\hline
\end{tabular}

$20 \mathrm{~h}$ in combustion mode $-596 \mathrm{~h}$ in gasification/reheat mode.

Table II. - Composition of product gases and temperature ranges at different positions.

\begin{tabular}{|c|c|c|c|c|c|}
\hline \multirow[t]{2}{*}{ Component } & Run $\AA$ & \multicolumn{2}{|r|}{ Run $B$} & \multicolumn{2}{|r|}{ Run $\mathrm{C}$} \\
\hline & $\begin{array}{l}\text { Coal } \\
\text { Feed }\end{array}$ & $\begin{array}{l}\text { Coal } \\
\text { Feed }\end{array}$ & $\begin{array}{c}\text { Coal and } \\
\text { Limestone Feed }\end{array}$ & $\begin{array}{l}\text { Coal } \\
\text { Feed }\end{array}$ & $\begin{array}{c}\text { Coal and } \\
\text { Limestone Feed }\end{array}$ \\
\hline $\mathrm{CO}$ & $N / A$ & $15.4 \%$ & $15.8 \%$ & $16.0 \%$ & $18.1 \%$ \\
\hline $\mathrm{CO}_{2}$ & $N / A$ & $11.2 \%$ & $11.2 \%$ & $10.0 \%$ & $8.8 \%$ \\
\hline $\mathrm{H}_{2}$ & $\mathrm{~N} / \mathrm{A}$ & $13.5 \%$ & $15.4 \%$ & $12.0 \%$ & $13.1 \%$ \\
\hline $\mathrm{CH}_{4}$ & $\mathrm{~N} / \mathrm{A}$ & $0.7 \%$ & $0.6 \%$ & $0.7 \%$ & $0.8 \%$ \\
\hline $\mathrm{N}_{2}$ & N/A & $59.3 \%$ & $57.0 \%$ & $60.0 \%$ & $59.2 \%$ \\
\hline Stean ${ }^{*}$ & $\mathrm{~N} / \mathrm{A}$ & $12.1 \%$ & $12.5 \%$ & $10.0 \%$ & $10.9 \%$ \\
\hline $\mathrm{H}_{2} \mathrm{~S}$ & $\mathrm{~N} / \mathrm{A}$ & 2500ppm & $377 \mathrm{ppm}$ & $1300 \mathrm{ppm}$ & $330 \mathrm{ppm}$ \\
\hline $\cos$ & $\mathrm{N} / \mathrm{A}$ & $114 \mathrm{ppm}$ & $49 \mathrm{ppm}$ & $88 \mathrm{ppm}$ & $65 \mathrm{ppm}$ \\
\hline $\mathrm{CS}_{2}$ & $\mathrm{~N} / \mathrm{A}$ & 22ppi & $\mathrm{N} / \mathrm{A}$ & $17 \mathrm{ppm}$ & 15ppm \\
\hline $\mathrm{HCl}$ & $\mathrm{N} / \mathrm{A}$ & $300 \mathrm{ppm}$ & $\mathrm{N} / \mathrm{A}$ & 112pp & $7 \mathrm{ppH}$ \\
\hline Top Probe Temp. & $700-840^{\circ} \mathrm{C}$ & & $80-920^{\circ} \mathrm{C}$ & & $00-870^{\circ} \mathrm{C}$ \\
\hline Middle Probe Temp. & $500-670^{\circ} \mathrm{C}$ & & $390-730^{\circ} \mathrm{C}$ & & $30-700^{\circ} \mathrm{C}$ \\
\hline Bottom Probe Temp. & $350-530^{\circ} \mathrm{C}$ & & $150-620^{\circ} \mathrm{C}$ & & $30-600^{\circ} \mathrm{C}$ \\
\hline
\end{tabular}

Compositions presented as percentage by volume (dry basis) except for percentage by weight.

2.2 EXPOSURE OF ELEMENTS AND COMPOUNDS AND ANALYSIS TECHNIQUES. - In an attempt to charaterise the in-situ plant atmosphere, an assessment has been made of the phase changes observed on the pure metals and compounds using basic thermodynamic principles. A series of powdered elements and compounds were exposed in alumina boats at the three sample locations during one full operational period of gasification (Run A). The elements exposed were $\mathrm{Co}, \mathrm{Fe}, \mathrm{Mo}, \mathrm{Cr}$ and $\mathrm{Nb}$, while the compounds were $\mathrm{Fe}_{2} \mathrm{O}_{3}, \mathrm{Cr}_{2} \mathrm{O}_{3}, \mathrm{MnCrO}_{4}, \mathrm{MnO}$ and $\mathrm{NbC}$. X-ray diffraction (XRD) analysis was carried out on the exposed samples. 
2.3 EXPOSURE OF ALlOYS AND ANALYSIS TECHNIQUES. - Table III shows the range of ten alloys exposed by clamping onto sample support bars in the three temperature ranges during two subsequent periods of gasification (Runs B and C). The elemental compositions of the alloys are given in table IV.

Table III. - Exposure locations of alloys.

\begin{tabular}{|c|c|c|}
\hline \multirow[b]{2}{*}{ Alloy } & \multicolumn{2}{|c|}{ Exposure Location } \\
\hline & Run $B$ & Bun $C$ \\
\hline $410 \mathrm{ss} / 347 \mathrm{ss} / 800 \mathrm{H} / 310 \mathrm{ss}$ & $\mathrm{T} \mathrm{H} B$ & I M B \\
\hline Haynes 150 / Haynes $230 /$ Haynes 160 & $-M B$ & -- \\
\hline Haynes 556 / Haynes 188 & $\mathrm{~T}-\mathrm{B}$ & -- \\
\hline MA956 & $-\cdots$ & T M - \\
\hline
\end{tabular}

Exposure Locations: $\mathrm{T}=$ Top $\mathrm{H}=$ Middle $\mathrm{B}=\mathrm{Bottom}$

Table IV. - Nominal compositions (wt\%) of exposed alloys.

\begin{tabular}{|c|c|c|c|c|c|c|c|c|c|c|c|c|}
\hline Alloy & $\mathrm{Fe}$ & $\mathrm{Ni}$ & $\mathrm{Cr}$ & AI & $\mathrm{Co}$ & $\mathrm{N}$ & $\mathrm{Hn}$ & $\mathrm{C}$ & si & $\mathrm{Ti}$ & Ho other & \\
\hline 410ss & $\mathrm{BaI}$ & - & 12 & - & - & - & - & - & - & - & - & \\
\hline $347 \mathrm{ss}$ & Bal & 11 & 18 & - & - & - & 2 & - & 1 & - & - & \\
\hline HA956 & Bal & - & 20 & 4.5 & - & - & - & - & - & 0.5 & $-0.5 Y_{2} \mathrm{O}_{3}$ & \\
\hline $800 \mathrm{H}$ & Bàl & 32 & 21 & 0.4 & - & - & $<1.5$ & 0.08 & $<1$ & 0.4 & $-<0.75 \mathrm{Cu}$ & \\
\hline Hayynes 556 & $\mathrm{Bal}$ & 20 & 22 & 0.3 & 20 & 2.5 & 1.5 & 0.1 & 0.4 & - & $\begin{array}{ll}3 & 0.02 \mathrm{La} \\
& 1 \text { Co+Ta }\end{array}$ & $\begin{array}{l}0.2 \mathrm{~N} \\
0.02 \mathrm{Zr}\end{array}$ \\
\hline $310 \mathrm{ss}$ & $\mathrm{Bal}$ & 20 & 25 & - & - & - & 2 & $=$ & 1.5 & - & - & \\
\hline Haynes 188 & $<3$ & 22 & 22 & - & $\mathrm{BaI}$ & 15 & - & $=$ & 0.35 & $5-$ & $-<0.015 \mathrm{~B}$ & $0.02 \mathrm{La}$ \\
\hline Haynes 150 & 20 & - & 28 & - & $\mathrm{Ba} l$ & - & 0.65 & 0.08 & 0.75 & $5-$ & - & \\
\hline Haynes 230 . & $<3$ & Bal & 22 & 0.3 & $<5$ & 14 & 0.5 & 0.1 & 0.4 & - & $2 \quad 0.005 \mathrm{La}$ & \\
\hline Haynes 160 & 4 & $\mathrm{Bal}$ & 28 & - & 27 & - & 0.5 & 0.05 & 2.75 & $5-$ & - & \\
\hline
\end{tabular}

After exposure, samples were metallographically prepared and examined by both optical microscopy and scanning electron microscopy with energy dispersive $\mathrm{x}$-ray analysis (SEM/EDX). 
The alloys were asssessed in terms of the thickness of any external scale, depth of any pits and the depth of any internal corrosion found on each sample.

\section{Results.}

3.1 GAS GHARACTERISATION. - The XRD analyses of the pure metals and compounds exposed in three probe positions are given in table $\mathrm{V}$. Each sample had become covered by a loose carbonaceous deposit during the plant exposure and, in a small number of cases, it was impossible to find the original sample. With these exceptions (and also in the case of occasional samples exhibiting an amorphous phase), valid results were obtained on a useful selection of samples from all three temperature ranges.

Table V. - XRD analysis of elements and compounds.

\begin{tabular}{|c|c|c|c|}
\hline \multirow{2}{*}{$\begin{array}{l}\text { Element } \\
\text { or } \\
\text { Compound }\end{array}$} & \multicolumn{3}{|c|}{ XRD Identification at particular exposure location } \\
\hline & Bottom & Middle & Top \\
\hline Co & $\mathrm{Co}(15) \mathrm{CO}_{2} \mathrm{~S}_{8}(100)$ & $\mathrm{CO}_{9} \mathrm{~S}_{8}(100) \mathrm{CO}_{4} \mathrm{~S}_{3}(5)$ & $\mathrm{CO}_{q} \mathrm{~S}_{8}(100) \mathrm{COO}(100)$ \\
\hline $\mathrm{Fe}$ & Fes $(100)$ & $\mathrm{Fe}_{3} \mathrm{O}_{4}(100) \mathrm{FeS}(40)$ & $\mathrm{Fe}_{3} \mathrm{O}_{4}(10) \mathrm{FeS}(100) \mathrm{Fe}_{1-x} \mathrm{~S}(100)$ \\
\hline Mo & $\mathrm{Ho}(100) \mathrm{Ho}_{3} \mathrm{~S}_{4}(50)$ & Amorphous phase & $\mathrm{HoO}_{2}(100) \quad \mathrm{MoS}_{2}(50) \mathrm{Ho}_{2} \mathrm{~S}_{3}(15)$ \\
\hline $\mathrm{Cr}$ & $\mathrm{Cr}(100) \mathrm{Cr}_{2} \mathrm{O}_{3}(10)$ & Amorphous phase & $N / A$ \\
\hline $\mathrm{Nb}$ & $\mathrm{Nb}(100) \mathrm{NbO}(10)$ & $\mathrm{N} / \mathrm{A}$ & N/A \\
\hline $\mathrm{Fe}_{2} \mathrm{O}_{3}$ & $\mathrm{Fe}_{3} \mathrm{O}_{4}(100)$ & $\begin{array}{l}\mathrm{Fe}_{2} \mathrm{O}_{3}(50) \mathrm{Fe}_{3} \mathrm{O}_{4}(50) \\
\mathrm{Fe}_{1-\mathrm{X}} \mathrm{S}(20)\end{array}$ & $\mathrm{Fe}_{2} \mathrm{O}_{3}(50)$ \\
\hline $\mathrm{Cr}_{2} \mathrm{O}_{3}$ & $\mathrm{Cr}_{2} \mathrm{O}_{3}(100)$ & $\mathrm{Cr}_{2} \mathrm{O}_{3}(100)$ & $\mathrm{Cr}_{2} \mathrm{O}_{3}(100)$ \\
\hline $\mathrm{HnCr}_{2} \mathrm{O}_{4}$ & $\mathrm{Hn}_{1.5} \mathrm{Cr}_{1.5} \mathrm{O}_{4}(100)$ & $\mathrm{N} / \mathrm{A}$ & $\mathrm{Hn}_{1.5} \mathrm{Cr}_{1.5} \mathrm{O}_{4}(100)$ \\
\hline Yno & $\operatorname{Mno}(10) \operatorname{Mns}(20)$ & $\mathrm{Mn}_{3} \mathrm{O}_{4}(50) \mathrm{KnS}(100)$ & $\mathrm{Hn}_{3} \mathrm{O}_{4}(100) \operatorname{MnS}(100)$ \\
\hline $\mathrm{NbC}$ & $\mathrm{NbC}(100) \mathrm{Nb}_{2} \mathrm{O}_{5}(20)$ & $\mathrm{NbO}_{2}(25) \mathrm{Nb}_{2} \mathrm{O}_{5}(100)$ & $\mathrm{Nb}_{2} \mathrm{O}_{5}(100)$ \\
\hline
\end{tabular}

$($ ) indicates the relative intensities of the peaks.

From the XRD results presented, it is noteworthy that of the valid results obtained from the $\mathrm{Co}, \mathrm{Fe}$ and Mo samples (the latter at the higher temperatures only), conversion of these elements to sulphides and, in most cases, oxides had occurred. In the case of the compounds which had been exposed, i.e. $\mathrm{Fe}_{2} \mathrm{O}_{3}, \mathrm{Cr}_{2} \mathrm{O}_{3}, \mathrm{MnO}$ and $\mathrm{MnCr}_{2} \mathrm{O}_{4}$, only the $\mathrm{MnO}$ and the $\mathrm{Fe}_{2} \mathrm{O}_{3}$ (at the middle probe position) were partially converted to the sulphides; the rest showed no discernible change. The $\mathrm{NbC}$ was converted to oxides, i.e. a mixture of $\mathrm{NbO}_{2}$ and $\mathrm{Nb}_{2} \mathrm{O}_{5}$ at the middle position, $\mathrm{Nb}_{2} \mathrm{O}_{5}$ at the top position whilst partial conversion to $\mathrm{Nb}_{2} \mathrm{O}_{5}$ has occurred at the lower postion. 
These results, which by necessity make a number of assumptions (see discussion), indicate that the reactant activities of the process gas during this period of gasification were as follows:

$$
\begin{aligned}
& 500^{\circ} \mathrm{C}=p_{\mathrm{S}_{2}} \geq 10^{-13} \text { bar } \leq 10^{-8} \text { bar; } p_{\mathrm{O}_{2}} \geq 10^{-28} \text { bar, } \\
& 650^{\circ} \mathrm{C}=p_{\mathrm{S}_{2}} \geq 10^{-10} \text { bar } \leq 10^{-7} \text { bar; } p_{\mathrm{O}_{2}} \geq 10^{-20} \text { bar, } \\
& 500^{\circ} \mathrm{C}=p_{\mathrm{S}_{2}} \geq 10^{-7.5} \text { bar } \leq 10^{-6} \text { bar; } p_{\mathrm{O}_{2}} \geq 10^{-15} \text { bar, }
\end{aligned}
$$

Thermodynamic phase stability diagrams for relevant $\mathrm{M}-\mathrm{S}-\mathrm{O}$ systems at temperatures of $800{ }^{\circ} \mathrm{C}, 650^{\circ} \mathrm{C}$ and $500^{\circ} \mathrm{C}$ have been selected and the results of the XRD observations have been superimposed on these. An example of that constructed for $650^{\circ} \mathrm{C}$ is shown in figure 2 .

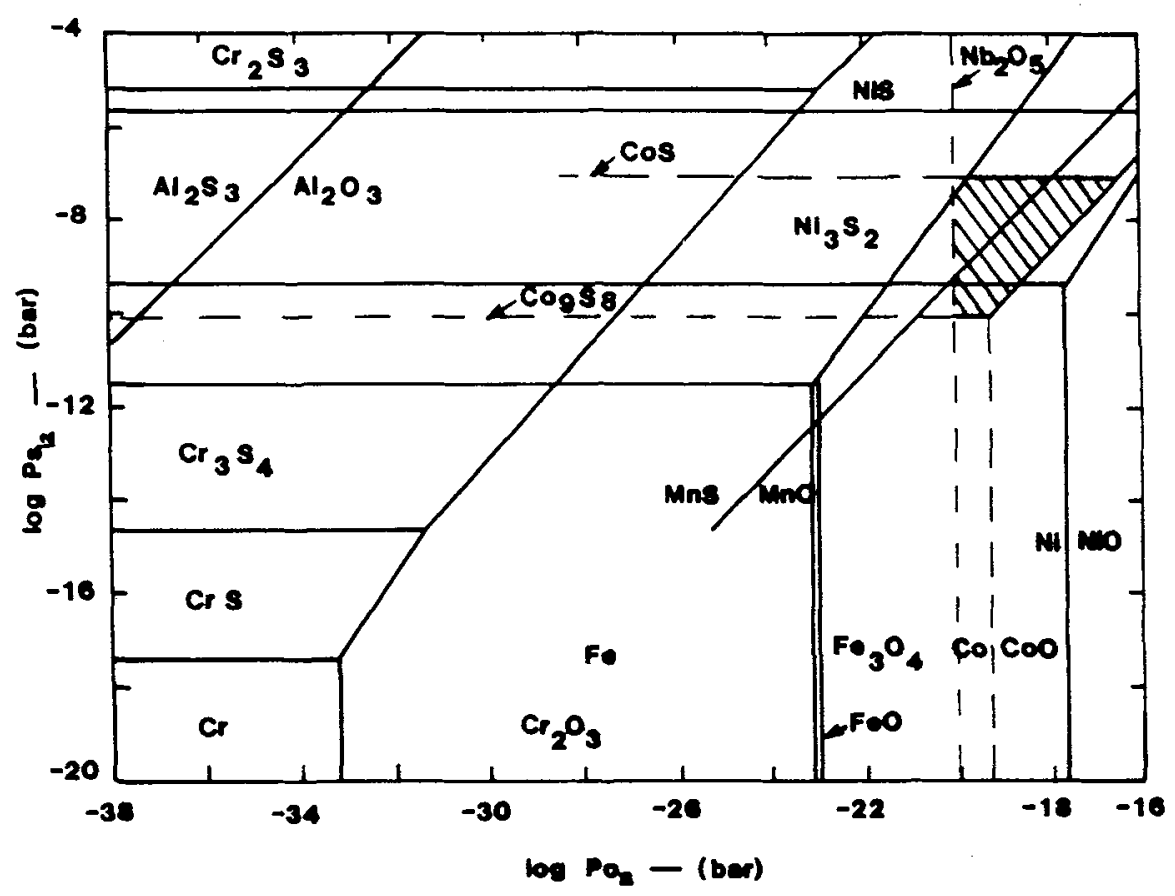

Fig. 2. - Thermodynamic phase stability diagram for selected M-S-O system at $650^{\circ} \mathrm{C}$.

3.2 METTALOGRAPHIC EXAMINATION OF ALLOYS. - The results of the metallographic examination of the alloys (summarised in Tab. VI) were as follows:

a) Fe-based alloys: 410 ss experienced extensive corrosion in the highest temperatures range, producing oxide/sulphide scales of up to $4 \mathrm{~mm}$ thick, whilst at the lower temperatures the samples contained pits of up to $50-100 \mu \mathrm{m}$. 347 ss produced oxide/sulphide scales of up to $2 \mathrm{~mm}$ in the highest exposure temperature range, with pits, some containing iron sulphides, of up to $125-160 \mu \mathrm{m}$ on the lower temperature probes.

For MA956 exposed at the higher temperature, the vast majority of the sample was covered in $\sim 10 \mu \mathrm{m}$ oxide scale, though this became $\mathrm{a} \sim 130 \mu \mathrm{m}$ thick oxide/sulphide scale near the 
Table VI. - Results of the metallographic examination of alloys exposed during runs $B$ and $C$.

\begin{tabular}{|c|c|c|c|}
\hline \multirow{2}{*}{$\begin{array}{l}\text { Alloy and } \\
\text { Exposure } \\
\text { Location }\end{array}$} & \multicolumn{3}{|c|}{ Corrosion Product ( $\mu$ m unless m stated) } \\
\hline & $\begin{array}{c}\text { Scale thickness } \\
\text { Run B/C }\end{array}$ & $\begin{array}{c}\text { Internal attack } \\
\text { Run } B / C \\
\end{array}$ & $\begin{array}{l}\text { Pit Depth } \\
\text { Run B/C }\end{array}$ \\
\hline $\begin{array}{l}410 s s-T \\
410 s s-M \\
410 s s-B \\
\end{array}$ & $\begin{array}{c}4 \mathrm{~mm} / 24 \\
12 / 20 \\
80 / 15 \\
\end{array}$ & $\begin{array}{ll}0 / 40 \\
0 / 10 \\
0 / 0 \\
\end{array}$ & $\begin{array}{c}0 / 305 \\
25 / 100 \\
0 / 50\end{array}$ \\
\hline $\begin{array}{l}347 s s-T \\
347 s s-11 \\
347 s s-B \\
\end{array}$ & $\begin{array}{c}2 \mathrm{~mm} / 20 \\
4 / 2 \\
10 / 4 \\
\end{array}$ & $\begin{array}{r}190 / 0 \\
10 / 0 \\
0 / 0\end{array}$ & $\begin{array}{c}0 / 0 \\
30 / 160 \\
14 / 125\end{array}$ \\
\hline $\begin{array}{l}\text { HA956-T } \\
\text { HA956- } \\
\end{array}$ & $\begin{array}{l}-/ 130^{*} \\
-/ 10 \\
\end{array}$ & $\begin{array}{l}-/ 160 \\
-/ 0 \\
\end{array}$ & $\begin{array}{l}-/ 20 \\
-/ 20 \\
\end{array}$ \\
\hline $\begin{array}{l}800 \mathrm{H}-\mathrm{T} \\
800 \mathrm{H}-\mathrm{H} \\
800 \mathrm{H}-\mathrm{B} \\
\end{array}$ & $\begin{aligned} & 20 / 15 \\
& 15 / 10 \\
& 4 / 2 \\
&\end{aligned}$ & $\begin{aligned} & 150 / 140 \\
& 75 / 20 \\
& 140 / 0 \\
&\end{aligned}$ & $\begin{array}{r}690 / 30 \\
40 / 20 \\
10 / 25\end{array}$ \\
\hline $\begin{array}{l}\text { Haynes } 556-\mathrm{T} \\
\text { Haynes } 556-\mathrm{B}\end{array}$ & $\begin{array}{r}650 /- \\
30 /-\end{array}$ & $\begin{array}{r}250 /- \\
0 /-\end{array}$ & $\begin{array}{r}400 /- \\
6 /-\end{array}$ \\
\hline $\begin{array}{l}310 \text { ss-T } \\
310 \text { ss- } \\
310 \text { ss-B } \\
\end{array}$ & $\begin{array}{c}80 / 120 \\
30 / 70 \\
1 / 20 \\
\end{array}$ & $\begin{array}{rll}20 & 0 \\
50 & 40 \\
2 & 42 \\
\end{array}$ & $\begin{aligned} 660 / 6 \\
6 / 50 \\
20 / 30 \\
\end{aligned}$ \\
\hline $\begin{array}{l}\text { Haynes } 188-\mathrm{T} \\
\text { Haynes } 188-\mathrm{B}\end{array}$ & $\begin{array}{r}50 /- \\
2 /- \\
\end{array}$ & $\begin{array}{r}60 /- \\
0 /- \\
\end{array}$ & $\begin{array}{r}800 /- \\
6 /-\end{array}$ \\
\hline $\begin{array}{l}\text { Haynes } 150-\mathrm{H} \\
\text { Haynes } 150-\mathrm{B} \\
\end{array}$ & $\begin{array}{l}2 /- \\
4 /- \\
\end{array}$ & $\begin{array}{r}60 /- \\
0 /= \\
\end{array}$ & $\begin{array}{r}40 /- \\
0 /-\end{array}$ \\
\hline $\begin{array}{l}\text { Haynes } 230-\mathrm{H} \\
\text { Haynes } 230-\mathrm{B} \\
\end{array}$ & $\begin{array}{l}2 /- \\
5 /-\end{array}$ & $\begin{array}{l}0 /- \\
0 /-\end{array}$ & $\begin{array}{r}0 /- \\
18 /-\end{array}$ \\
\hline $\begin{array}{l}\text { Haynes } 160-\mathrm{H} \\
\text { Haynes } 160-\mathrm{B}\end{array}$ & $\begin{array}{l}4 /= \\
2 /=\end{array}$ & $\begin{array}{l}0 /= \\
0 /=\end{array}$ & $\begin{array}{l}0 /- \\
0 /-\end{array}$ \\
\hline
\end{tabular}

Exposure Locations: T=Top k=Middle B=Bottom

"Only in small area of sample near corner - otherwise 10um oxide scale

corner of the sample, where internal attack of $160 \mu \mathrm{m}$ was also present. Analysis showed that the scale was a chromium-rich oxide with an aluminium-rich inner layer (Fig. 3). In places there were some sulphides in the scale and occasionally there were internal sulphides. A sample exposed in the middle temperature range contained a protective aluminium-rich scale beneath $\mathrm{a} \sim 10 \mu \mathrm{m}$ iron sulphide scale, as well as a little pitting of up to $20 \mu \mathrm{m}$ depth.

Alloy $800 \mathrm{H}$ produced an oxide/sulphide scale of $\sim 20 \mu \mathrm{m}$ at the highest temperature with pitting and internal attack in all ranges. Sulphides were observed within pits on the lower temperature sample.

Haynes 556 experienced severe corrosion in the highest temperature range, with an ox- 


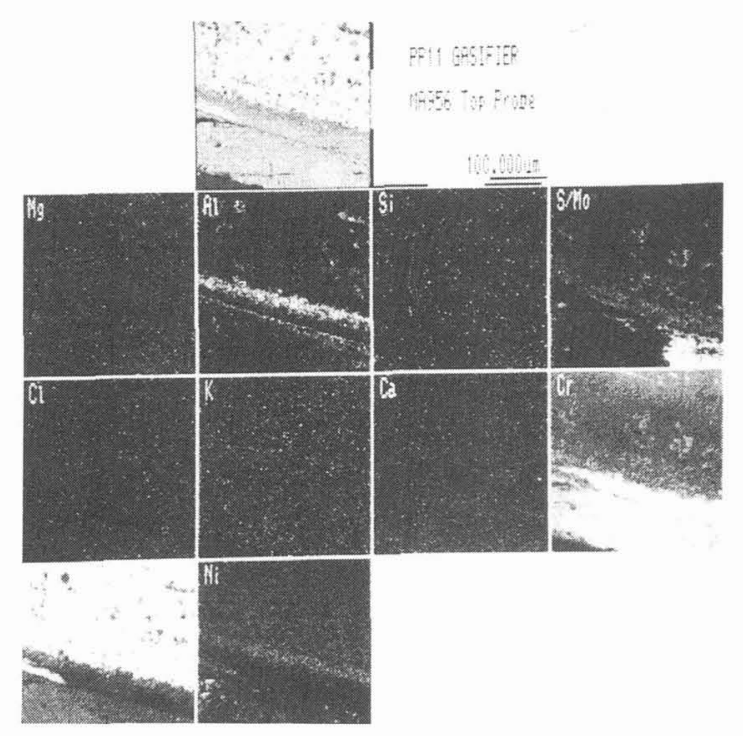

Fig. 3. - SEM/EDX digimap analysis of an MA956 sample exposed at the highest exposure temperature.

ide/sulphide surface scale and internal sulphidation along grain boundaries. In the lowest temperature range, a sulphide containing oxide scale up to $\sim 30 \mu \mathrm{m}$ thick was present on top of a thin chromia-rich scale at the surface.

310 ss produced thick oxide/sulphide scales in the highest temperature ranges in both runs. In the middle temperature range, the 310 ss samples had pits to a depth of $50 \mu \mathrm{m}$ with internal sulphidation beneath a chromium-rich scale. In the lower temperature range, some sulphides were observed within a $\sim 20 \mu \mathrm{m}$ oxide scale, which had an iron and nickelrich outer layer (Fig. 4); in addition, pits of up to $30 \mu \mathrm{m}$ were also present.

b) Co-based alloys: Haynes 188 produced thick oxide/sulphide scales in the highest temperature range. Haynes 150 contained internal sulphidation to a depth of $60 \mu \mathrm{m}$ beneath a chromium-rich scale in the middle temperature range. Only very thin oxide scales were present on these alloys in the lowest temperature range.

c) Ni-based alloys: Haynes 230 and Haynes 160 exposed in the middle and lowest temperature ranges both formed a thin protective chromium-rich oxide scale, with the only other sign of corrosion being some small pits (of $\sim$ upto $18 \mu \mathrm{m}$ ) on the lowest temperature Haynes 230 .

\section{Discussion.}

4.1 GaS CHARACTERISATION. - The use of powdered elements and alloys to characterise the activities of species within the coal gasification gases is a simple method, although there are limitations in this simplistic approach, e.g.:

(a) the temperature ranges quoted for each probe position were of the order of $150^{\circ} \mathrm{C}$ but it has been necessary to select a single temperature from within each range for assessment;

(b) basic assumptions concerning gas phase equilibria have had to be made; 


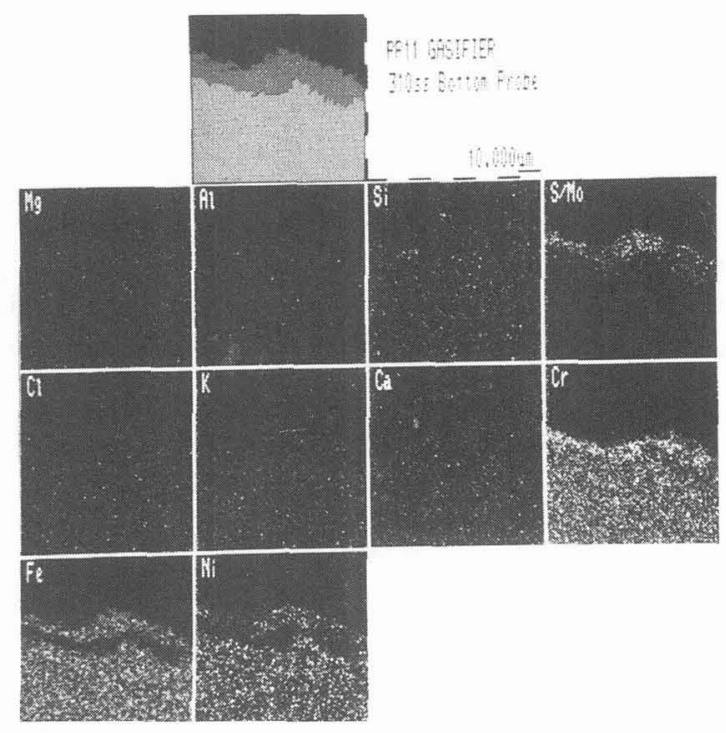

Fig. 4. - SEM/EDX digimap analysis of a 310 ss sample exposed at the lowest exposure temperature.

(c) reaction kinetics will obviously play an important role but this factor has not been considered.

However, this technique has enabled the character of the plant atmosphere, depicted in the form of "activity windows", to be derived for the reactants $\mathrm{S}$ and $\mathrm{O}$ at each of the three probe positions.

4.2 ALLOY PERFORMANCE. - The exposure of several alloys based on iron, cobalt or nickel has allowed a comparative assessment of corrosion resistance of these alloys to be made in three different temperature ranges of industrial interest (evaporator, superheater and ductwork).

It should be noted that the relatively low chromium content alloys 410 ss and 347 ss ( 12 and $18 \% \mathrm{Cr}$ respectively) experienced excessive corrosion in all the temperature ranges tested. The results of this study also suggest that $800 \mathrm{H}$ is little more corrosion resistant than $347 \mathrm{ss}$ in this type of atmosphere; which is consistent with the observations made in work using a laboratory simulated gasification atmosphere at $700^{\circ} \mathrm{C}[5]$.

In the highest temperature range MA956 was found to be the least damaged alloy, with a thin adherent scale covering most of the sample surfaces (excessive corrosion at the corners of samples is common in corrosion testing [5] and it is felt may be ignored). This good performance of MA956 is consistent with previous studies in similar environments [6, 7]. 310 ss was the best of the other alloys tested in this temperature range.

In the middle temperature range, MA956 again performed well, and the performances of 310 ss, as well as the Haynes alloys 150, 160 and 230 were encouraging. Similar performances of Haynes 160 in a laboratory gasification atmosphere at $700^{\circ} \mathrm{C}$ has been reported elsewhere [5].

In the lower temperature range all the Haynes alloys and 310 ss performed well, though there were signs of sulphides forming in some of the protective chromia scales and signs of 
some pitting.

These results suggest that at least for the 600 hours exposure to the coal gasifier gases used in this study, chromia oxide scales can be protective at temperatures below $\sim 700{ }^{\circ} \mathrm{C}$, with the chromia/alumina scales formed on MA956 being protective to higher temperatures.

Most of the corrosion damage observed on the alloys in this study was caused by high temperature corrosion, though the presence of a small number of pits may indicate some downtime corrosion may be anticipated in a real plant. When selecting alloys for use in a real plant other materials issues will also need to be considered, such as the waterside corrosion performance in heat exchangers, the joining of alloys, the cost of materials etc.

\section{Conclusions.}

The exposure of ten reference elements and compounds in three temperature ranges in the hot gas path of British Coal's large scale atmospheric fluidised bed coal gasifier has enabled the process atmosphere to be characterised. Analyses of the samples after exposure have enabled "activity windows" for $\mathrm{S}$ and $\mathrm{O}$ to be derived.

Analysis of a range of alloys exposed to 600-660 hours of coal gasification atmosphere has shown that MA956 formed a protective oxide layer even at $900^{\circ} \mathrm{C}$, whilst alloys containing $22-28 \%$ chromium formed protective oxide layers at temperatures below $700^{\circ} \mathrm{C}$.

$410 \mathrm{ss}, 347 \mathrm{ss}$ and $800 \mathrm{H}$ were unsatisfactory for long term usage in any of the temperature ranges investigated.

\section{Acknowledgements.}

The views expressed in this paper are those of the authors, and not necessarily those of the parent organisations.

\section{References}

[1] Simms N.J., Oakey J.E., Smith M.A., Materials for Combined cycle Power Plant (Institute of Metals, 1991) p. 229.

[2] Kofstad P., High Temperature Corrosion (Elsevier, 1988).

[3] Lloyd D.M., Research and Development of High Temperature Materials, E. Bullock Ed. (Elsevier, 1989) p. 339.

[4] Gale J.J. et al., J. Inst. Energy (September, 1991) p. 143.

[5] Norton J.F. et al., High Temperature Materials for Power Engineering Part I, E. Bachelet et al. Eds. (Kluwer, 1990) p. 167.

[6] Lloyd D.M., Frontiers of High Temperature Materials II, J.S. Benjamin and R.S. Benn Eds.

[7] Santorelli R.L. et al., High Temperature Materials for Power Engineering Part I, E. Bachelet et al. Eds. (Kluwer, 1990) p. 177. 